Selcuk Journal of Agriculture and Food Sciences

http://sjafs.selcuk.edu.tr/sjafs/index

Research Article
SJAFS

(2021) 35 (2), 131-135

e-ISSN: $2458-8377$

DOI:10.15316/SJAFS.2021.239

\title{
Physical Characteristics and Natural Flow Rates of Dry Bean Cultivars of a Local Population Grown in Konya Province of Turkey
}

\author{
iD Mehmet ARIKAYMAK ${ }^{1}$, (iD Haydar HACISEFEROĞULLARI ${ }^{1, *}$
}

${ }^{1}$ Selçuk University, Faculty of Agriculture, Department of Agricultural Machinery and Technologies Engineering, Konya, Turkey

\begin{tabular}{l}
\hline ARTICLE INFO \\
\hline Article history: \\
Received date: 12.04 .2021 \\
Accepted date: 23.06 .2021 \\
\hline
\end{tabular}

\section{Keywords:}

Bean

Physical properties

Surface roughness

Natural flow rate

\begin{abstract}
In the present study, physical characteristics of some dry bean cultivars (Sarikiz, Basara and Horoz) of a local population grown in Konya province of Turkey were determined and an experimental test set up was used to investigate flow rates on different surfaces (galvanized sheet, plain sheet and painted sheet iron) and different conveyor channel angles $\left(24^{0}, 28^{0}, 32^{\circ}, 36^{\circ}\right)$. In Sarikiz, Basara and Horoz dry bean cultivars respectively at 10.85, 9.63 and 9.12\% moisture levels, average grain lengths were respectively measured as $11.51,17.56$ and $15.09 \mathrm{~mm}$; average widths $7.21,10.40$ and $7.31 \mathrm{~mm}$; average thicknesses as 5.11, 4.92 and $5.76 \mathrm{~mm}$; average geometric mean diameters as $7.51,9.64$ and $8.59 \mathrm{~mm}$; sphericity values as $0.65,0.55$ and 0.57 ; angle of repose values as $20.07^{0}, 21.99^{\circ}$ and $18.53^{\circ}$; thousand-kernel weights as 229.60 , 514.93 and $426.67 \mathrm{~g}$; bulk densities as $682.72,696.65$ and $779.17 \mathrm{~kg} \mathrm{~m}^{-3}$. Static coefficient of friction values of the same cultivars (Sarikiz, Basara and Horoz) on galvanized, painted and plain sheet surface were respectively measured as $0.356,0.441$ and $0.427 ; 0.350,0.428$ and $0.396 ; 0.344,0.401$ and 0.383. In Horoz dry bean cultivar, the flow was seen on all surfaces and at all channel angles. However, there was no flow in Sarıkız and Basara cultivars on painted sheet surface at $24^{\circ}$ channel angle and no flow in Sarıkız cultivar on plain sheet surface at $24^{\circ}$ channel angle. Among the cultivars, the greatest average flow rate $\left(1.61 \mathrm{~kg} \mathrm{~s}^{-1}\right)$ was achieved in Horoz dry bean cultivar and such a flow rate was mostly designated by grain physical characteristics and surface profile. Surface roughness influenced flow rates and the greatest flow rate on galvanized sheet surface with the lowest surface roughness was measured as $1.66 \mathrm{~kg} \mathrm{~s}^{-1}$. The greatest flow rate was obtained from $36^{0}$ conveyor channel angle $\left(2.01 \mathrm{~kg} \mathrm{~s}^{-1}\right)$. Present findings revealed that physical characteristics of the cultivars, channel roughness and angle influenced flow rates.
\end{abstract}

\section{Introduction}

With the increasing world population, human nutrition has become an important issue. Decreasing agricultural lands per capita, changing consumer demands and the formation of a wide range of consumptions entail the development of several high-yield varieties. Pulses including beans, lentils, broad beans and cowpea play a great role in the solution of human nutritionrelated problems.

Beans are consumed as fresh or dry bean. Beans are rich in protein and the amino acid composition of bean proteins is quite close to meat protein. Beans are also rich in carbohydrates, calcium, iron and especially phosphorus, thus have a superior position over the similar foodstuffs. On the other hand, sulphur-

\footnotetext{
* Corresponding author email: hhsefer@selcuk.edu.tr
}

containing amino acid content of beans is greater than the edible pulses, thus the biological value of bean protein is high (Çavuşoğlu and Akçin 2007).

Dry bean (white bean) production areas, yield and production of Turkey and Konya province are provided in Table 1. According to 2020 data, in Konya province, dry bean farming was practiced over 185900 da land areas and total production was 62408 tons. Dry bean cultivated lands of Konya province constitute $18.5 \%$ of the country production area and 22.335 of country production. Yield levels are also $124 \%$ greater than the country average.

Local cultivars are highly adapted to growing the region, have a high-quality trait and mostly emerged through local selections. Today, mostly the local cultivars are grown and served to markets. These cultivars are also used in breeding studies conducted to develop new cultivars Since the local cultivars are grown with the use of conventional farming systems, the produc- 
tion of these cultivars does not comply with organic farming principles.

The physical and mechanical properties of grains play an important role in the selection of storage Table 1 Dry bean cultivation area, yield and productions of Turkey and Konya province (TÜİK, 2021)

\begin{tabular}{lcccccc}
\hline & \multicolumn{2}{c}{ Cultivated land $(\mathrm{da})$} & \multicolumn{2}{c}{ Yield $\left(\mathrm{kg} \mathrm{da}^{-1}\right)$} & \multicolumn{2}{c}{ Production (ton) } \\
\cline { 2 - 7 } Years & Konya & Turkey & Konya & Turkey & \multicolumn{2}{c}{ Konya } \\
Turkey \\
\hline 2015 & 191849 & 935840 & 380 & 251 & 72869 & 235000 \\
2016 & 202234 & 898197 & 367 & 265 & 69877 & 235000 \\
2017 & 191438 & 897221 & 367 & 267 & 70242 & 239000 \\
2018 & 148111 & 848045 & 361 & 259 & 53439 & 220000 \\
2019 & 148331 & 889385 & 335 & 253 & 49664 & 225000 \\
2020 & 185900 & 1029857 & 336 & 271 & 62408 & 279518 \\
\hline
\end{tabular}

Flow characteristics of granular products cannot be explained by fluid mechanics and hydrodynamic principles. Some agricultural products flow more easily as compared to the others. Non-uniform pressure distribution and frictional forces between the particles lead to problems such as product caking during storage, nonuniform arching and channeling etc.

The orifice shape and physical properties of the material affect the flow rate of the material. The shape of the grain and the grain shape distribution play an important role in flowability, while the unit weight affects the internal friction angle and compressibility of grain (Fitzpatrick et al. 2004).

Many studies have focused on the material flow rate, the relationship between flow rate and material properties and the regularity of the flow in various orifices. For instance, Mohsenin (1986) investigated the factors affecting grain flow such as bin geometry, orifice shape, height / diameter ratio of orifice factors and obtained several mathematical equations which define the grain flow.

Kara and Ozturk (1997) investigated the factors that affect the flow from the orifice in the different formats of grain products and developed mathematical equations to find the flow rate of the products.

Elaskar et al. (2001) recorded a video of the flow from rough and smooth channels of sorghum and obtained velocity profiles. Researchers reported $113 \%$ increase in velocity when the sliding surface slope angles increase from $18^{0}$ to $38^{0}$; they found that the maximum velocity occurred at a slope angle of $37^{\circ}$; and the flow rate increased $377 \%$ when the slope angle was increased from $30^{\circ}$ to $37^{\circ}$.

Akar (2003) reported that natural flow rates of Sultani and Amasya okra varieties changed depending on the moisture condition, the flow angle and type of channel. The study determined that flow rates of both varieties decreased as the moisture content increased and there was no natural flow for a slope angle of $30^{\circ}$ with respect to the moisture content. Furthermore, the highest flow rate values for both varieties were obtained when using a galvanized steel channel. equipment and design of storage structures (Kashaninejad et al. 2006).
In Turkey, there are several ongoing investigations on the flow profiles of granular products in silos (Ozturk et al. 2008a) and design loads for nuts and corn in storage buildings (Ozturk et al. 2008b;c).

In the transport of grain products by mechanical transmission systems, the loading and unloading system transmission channels and the slope angle of the base walls of the silo are extremely important for a continual natural flow. Therefore, in this study, the natural flow rates of some dry beans varieties were determined for different flow surfaces and angles. Some physical characteristics and natural flow rates of dry beans of a local population were determined for different flow surfaces and angles.

\section{Materials and Methods}

Sarıkı, Basara and Horoz dry bean varieties, all of which are cultivated in Konya province, were used as the material of the present experiments.

The thousand grain weight of beans were measured by using an electronic balance with an accuracy of $\pm 0.001 \mathrm{~g}$. Initially, 100 grains were taken randomly in three replicates for each variety to measure the thousand grain weight. Dimensional properties of grains were measured by using a micrometer with $\pm 0.01 \mathrm{~mm}$ accuracy. Geometric mean diameter $\left(D_{\mathrm{g}}\right)$ and sphericity $(\varnothing)$ values were calculated with the use of the following equations (Mohsenin 1986).

$$
\begin{aligned}
& D_{g}=(L W T)^{0.333} \\
& \varnothing=(L W T)^{0.333} / L
\end{aligned}
$$

Where,

$\mathrm{D}_{\mathrm{g}}:$ Geometric mean diameter $(\mathrm{mm})$

$\varnothing$ : Sphericity (-)

$\mathrm{L}$ : Length of grain (mm)

$\mathrm{W}$ : Width of grain $(\mathrm{mm})$

$\mathrm{T}$ : Thickness of grain (mm)

To determine the angle of repose, the materials were slowly poured on a flat surface freely. Poured materials formed a cone on the surface. The angles of repose were determined by calculating the tangent 
value (internal friction coefficient) of the horizontal angle of this cone (angle of repose).

Each cultivar was poured into a one-liter glass vessel with the velocity of $12 \mathrm{~s} / \mathrm{L}$. After pouring, the vessel top was leveled off, then the weight of the material was determined. The resultant weight was divided by the volume of the vessel to get the bulk density of the material.

The coefficient of static friction was measured by using sheet iron, galvanized sheet iron and painted sheet surfaces. For this measurement, one end of the friction surface is attached to an endless screw. Dry bean samples were placed on the surface and it was gradually raised by the screw. Vertical and horizontal height values were read from the ruler when the grain started sliding over the surface, then using the tangent value of that angle, the coefficient of static friction was found. Baryeh (2001) and Gezer et al. (2003) have used similar methods.

The flow rate values were determined in the experimental test unit, which was constructed specifically for this purpose. The experimental test unit consists of a cylindrical feeding hopper, which has a funnelshaped exit with a capacity of five liters; an unloading cover can be opened easily at the bottom of the hopper, and a channel conveyor. The channel conveyors which have three different surfaces and have a $0.5 \mathrm{~m}$ length, were used in the experiment. These channels consist of: formed steel, galvanized steel and painted steel sheet. A special structure was constructed to support the hopper and the channel. A schematic view of this experimental test unit is given in Figure 1.

During the trials, after a funnel-shaped hopper was filled with material, the unloading cover at the bottom of the storage was opened, and the digital chronometer was operated simultaneously. After all of the material entered into the channel conveyor, the chronometer was stopped and the elapsed time was determined. These values were divided by the mass of the material, and the natural flow rates were determined in three replicates

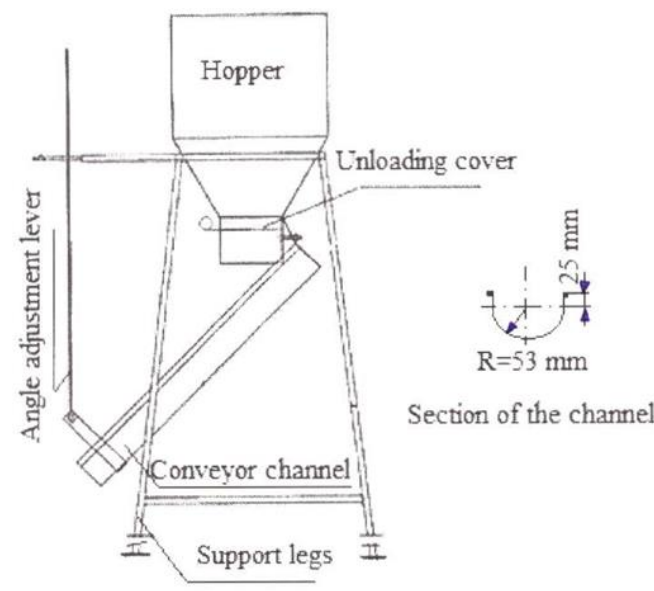

Figure 1

A schematic view of the natural flow test unit and section of the channel
There are three values to define surface roughness: $\mathrm{Ra}$ (the mathematical average roughness value), $R_{z}$ (the measured roughness value) and $R \max$ (the biggest surface roughness). $R_{a}, R_{z}$ and $R_{\max }$ values were measured by the profile-meter device (measurement range of 0-150 $\mu \mathrm{m}$, Marsurf brand) in the three replicates.

Experimental data were subjected to ANOVA with the use of the General Linear Model of MINITAB 16 software. Significant means were compared with the use of Tukey's multiple range test.

\section{Results and Discussion}

Physical characteristics of present dry bean cultivars are provided in Table 2. The greatest grain length, width, geometric mean diameter and angle of repose values were obtained from Basara cultivar respectively with $17.57 \mathrm{~mm}, 10.40 \mathrm{~mm}, 9.64 \mathrm{~mm}$ and $21.99^{\circ}$. In Basara cultivar, low values of thickness and sphericity (4.92 $\mathrm{mm}$ and 0.55 ) were observed. The greatest bulk density $\left(779.17 \mathrm{~kg} \mathrm{~m}^{-3}\right)$ was obtained from Horoz cultivars and the lowest bulk density $\left(682.72 \mathrm{~kg} \mathrm{~m}^{-3}\right)$ Sarıkız cultivar. The thousand-grain weight of Sarıkı, Basara and Horoz cultivars was respectively measured as $229.60,514.93$ and $426.67 \mathrm{~g}$. The coefficient of static friction values for galvanized sheet, painted sheet and steel sheet surfaces varied from 0.344 to 0.441 .

The lowest values were obtained from the galvanized sheet surface and the highest values from the painted sheet surface. Güngör and Güvenç (1996) conducted a study on registered dry bean cultivars of Turkey and reported that grains lengths varied between 8.6 $\mathrm{mm}$ (Karacaşehir) and $15.5 \mathrm{~mm}$ (Şahin-90), grain widths between $5.5 \mathrm{~mm}$ (Karacaşehir-90) and $7.7 \mathrm{~mm}$ (Şeker), grain thicknesses between $4.6 \mathrm{~mm}$ (Karacaşehir-90) and $6.7 \mathrm{~mm}$ (Şeker), and thousand grain weights between 209.1 g (Karaeaşehir-90) and 467,6 g (Yunus-90). Işık and Unal (2007) conducted a study on white speckled red kidney bean grains at $9.77 \%$ moisture level and reported geometric mean diameter as $9.38 \mathrm{~mm}$ and sphericity value as 0.734 . Present findings on physical characteristics comply with literature findings.

The changes in $R_{a}, R_{z}$, and $R_{\max }$ values, which determine the surface roughness of the channel conveyors, are given in Table 3. The maximum values of roughness $\left(R_{\max }\right)$, the mathematical mean roughness values $\left(R_{a}\right)$ and the measured roughness values $\left(R_{z}\right)$ of the galvanized sheet surface, the steel sheet surface and the painted sheet surface were found to be $6.20,8.12$ and $19.18 ; 1.13,1.20$ and $2.06 ; 4.83,6.42$, and 11.56, respectively.

The natural flow rate values for different surfaces and channel conveyor angles are provided in Table 3. By increasing the channel conveyor angles, the natural flow rate values increased on all surfaces. For the channel angle of $24^{\circ}$ and painted sheet surface, it was observed that there was no flow in Sarıkız and Basara dry bean cultivars. Again, in the Sarıkız cultivar, there 
was no flow on the plain sheet surface at $24^{\circ}$ channel angle. Such a case was because of high static coeffi-

Table 2

Some physical characteristics of dry bean grains

\begin{tabular}{lccc}
\hline Characteristics & Sarıkı cultivar & Başara cultivar & Horoz cultivar \\
\hline Moisture $(\%)$ & 10.85 & 9.63 & 9.12 \\
Lenght (mm) & $11.51 \pm 0.12$ & $17.56 \pm 0.17$ & $15.09 \pm 0.13$ \\
Width (mm & $7.21 \pm 0.07$ & $10.40 \pm 0.08$ & $7.31 \pm 0.06$ \\
Thickness (mm) & $5.11 \pm 0.05$ & $4.92 \pm 0.08$ & $5.76 \pm 0.05$ \\
Geometric mean diameter (mm) & $7.51 \pm 0.061$ & $9.64 \pm 0.076$ & $8.59 \pm 0.060$ \\
Sphericity (-) & $0.65 \pm 0.003$ & $0.55 \pm 0.004$ & $0.57 \pm 0.002$ \\
Angle of repose $\left({ }^{0}\right)$ & $20.07 \pm 0.56$ & $21.99 \pm 0.71$ & $18.53 \pm 0.98$ \\
Thousand-grain weight $(\mathrm{g})$ & $229.60 \pm 1.71$ & $514.93 \pm 3.41$ & $426.67 \pm 6.67$ \\
Bulk density $\left(\mathrm{kg}^{-3}\right)$ & $682.72 \pm 4.13$ & $696.65 \pm 4.92$ & $779.17 \pm 3.65$ \\
\hline Static coefficient of friction & & & \\
\hline Galvanized sheet surface & $0.356 \pm 0.011$ & $0.350 \pm 0.017$ & $0.344 \pm 0.010$ \\
Painted sheet surface & $0.441 \pm 0.015$ & $0.428 \pm 0.011$ & $0.401 \pm 0.013$ \\
Steel sheet surface & $0.427 \pm 0.013$ & $0.396 \pm 0.010$ & $0.383 \pm 0.014$ \\
\hline
\end{tabular}

Table 3

Surface roughness values

\begin{tabular}{lccc}
\hline & $\mathrm{R}_{\max }$ & $\mathrm{R}_{\mathrm{a}}$ & $\mathrm{R}_{\mathrm{z}}$ \\
\hline Galvanized sheet surface & $6.20 \pm 0.35$ & $1.13 \pm 0.06$ & $4.83 \pm 0.27$ \\
Plain sheet surface & $8.12 \pm 0.74$ & $1.20 \pm 0.06$ & $6.42 \pm 0.30$ \\
Painted sheet surface & $19.18 \pm 3.84$ & $2.06 \pm 0.07$ & $11.56 \pm 1.14$ \\
\hline
\end{tabular}

In Horoz cultivar, grain flow on painted sheet surface (with high roughness) at $24^{0}$ channel angle was mostly resulted from low angle of repose of the materi-

Table 4

Natural flow rates over different surfaces and at different channel conveyor angles $\left(\mathrm{kg} \mathrm{s}^{-1}\right)$

\begin{tabular}{|c|c|c|c|c|}
\hline & \multicolumn{4}{|c|}{ Conveyor channel angle } \\
\hline & $24^{\circ}$ & $28^{\circ}$ & $32^{\circ}$ & $36^{\circ}$ \\
\hline \multicolumn{5}{|c|}{ Galvanized sheet surface } \\
\hline Sarıkız cultivar & $0.87 \pm 0.0_{\mathrm{jk}}$ & $1.50 \pm 0.02_{\mathrm{f}}$ & $1.87 \pm 0.03_{\mathrm{cd}}$ & $2.07 \pm 0.05 \mathrm{~b}$ \\
\hline Başara cultivar & $0.91 \pm 0.02_{\mathrm{j}}$ & $1.47 \pm 0.01_{\mathrm{fg}}$ & $1.77 \pm 0.05_{\text {cde }}$ & $1.91 \pm 0.04_{\mathrm{c}}$ \\
\hline Horoz cultivar & $1.26 \pm 0.02 \mathrm{~h}_{1}$ & $1.85 \pm 0.01_{\mathrm{cd}}$ & $2.17 \pm 0.01_{\mathrm{ab}}$ & $2.26 \pm 0.01_{\mathrm{a}}$ \\
\hline \multicolumn{5}{|c|}{ Painted sheet surface } \\
\hline Sarık1z cultivar & - & $1.15 \pm 0.01_{1}$ & $1.67 \pm 0.01_{\mathrm{e}}$ & $1.83 \pm 0.01_{\mathrm{cd}}$ \\
\hline Başara cultivar & - & $1.35 \pm 0.01_{\mathrm{gh}}$ & $1.68 \pm 0.02 \mathrm{e}$ & $1.84 \pm 0.01_{\mathrm{cd}}$ \\
\hline Horoz cultivar & $1.22 \pm 0.01_{\mathrm{h} 1}$ & $1.65 \pm 0.03_{\mathrm{e}}$ & $1.89 \pm 0.01_{\mathrm{cd}}$ & $2.06 \pm 0.02 \mathrm{~b}$ \\
\hline \multicolumn{5}{|c|}{ Plain sheet surface } \\
\hline Sarıkız cultivar & - & $1.23 \pm 0.03 \mathrm{~h}_{1}$ & $1.82 \pm 0.02 \mathrm{~cd}$ & $2.05 \pm 0.02 b$ \\
\hline Başara cultivar & $0.76 \pm 0.02 \mathrm{k}$ & $1.41 \pm 0.01_{\mathrm{fg}}$ & $1.75 \pm 0.02 \mathrm{de}$ & $1.89 \pm 0.01_{\mathrm{cd}}$ \\
\hline Horoz cultivar & $1.26 \pm 0.02 \mathrm{~h}_{1}$ & $1.83 \pm 0.04 \mathrm{~cd}$ & $2.11 \pm 0.04 \mathrm{ab}$ & $2.12 \pm 0.03_{\mathrm{ab}}$ \\
\hline
\end{tabular}

In terms of average flow rates, the greatest value was measured as $1.61 \mathrm{~kg} \mathrm{~s}^{-1}$ in Horoz cultivar, $1.40 \mathrm{~kg}$ $\mathrm{s}^{-1}$ in Basara cultivar and $1.34 \mathrm{~kg} \mathrm{~s}^{-1}$ in Sarıkız cultivar and the differences in natural flow rates of the cultivars were found to be significant $(\mathrm{p}<0.05)$. High flow rate of Horoz cultivar was attributed to grain surface profile with low angle repose and static coefficient of friction.

Increasing flow rates were observed on galvanized sheet surface with increasing conveyor channel angles. On this surface, the flow rate increase ratio in Sarıkı, Basara and Horoz cultivars was respectively calculated as 240,210 and $179 \%$. Such increases on painted sheet surface were respectively calculated as 159, 136 and $169 \%$ and increases on plain sheet surface were respec- cient of friction (friction angle) of the grains on these surfaces. al. The angle of repose of granular materials plays an important role in design of conveyors.

Variance analysis on natural flow rates of different dry bean cultivars at different channel angles on different conveyance surfaces revealed that there were significant relationships between all parameters and levels (Table 4). The highest flow rate value was obtained as $2.26 \mathrm{~kg} \mathrm{~s}^{-1}$ in the horoz bean variety, on the galvanized sheet surface and at the 36 degree conveyor channel angle. 
$\mathrm{s}^{-1}(\mathrm{p}>0.05)$. High channel angles increased flow rates and decreased flow depths. Elaskar et al. (2003) indicated that flow rate and maximum stable flow depth of sorghum grains exhibited almost a linear relationship with channel angle.

\section{Conclusion}

There were significant differences in physical characteristics of dry bean cultivars of a local population grown in Konya province. There was no flow in Sarıkı and Basara cultivars on painted sheet surface at $24^{\circ}$ channel angle and no flow in Sarikız cultivar on plain sheet surface at $24^{\circ}$ channel angle. Therefore, to achieve flow on these surfaces, a greater channel angle than the static coefficient of friction (friction angle) should be selected. Such an issue should be taken into consideration especially for surfaces with high surface roughness. Present observations revealed that periodical cleaning of the channel base will lead to greater flow rates. In the present study, experimental observations were presented without a theory. Further research is recommended for velocity profiles and flow characteristics of granular materials.

\section{References}

Akar R (2003). Konya'da yetiştirilen bamya çeşitlerinin bazı teknolojik özellikleri. Yüksek Lisans Tezi, Selçuk Üniversitesi Fen Bilimleri Enstitüsü, Tarım Makineleri Anabilim Dalı (Basılmamış), Konya.

Baryeh EA (2001). Physical properties of bambara groundnuts. Journal of Food Engineering 47(4): 321-326.

Çavuşoğlu A, Akçin A (2007). Taze fasulye (Phaseolus vulgaris L.) çeşitlerinde farklı gübre kombinasyonlarının verim ve verim unsurları üzerine etkileri, Selçuk Tarım Bilimleri Dergisi 21(43): 106-111.

Elaskar SA, Godoy A, Mateo D, Seeber G (2001). PHPostharvest Technology: An Experimental Study of the Gravity Flow of Sorghum. Journal of Agricultural Engineering Research 79(1): 65-71.
Eşref I, Halil U (2007). Moisture-dependent physical properties of white speckled red kidney bean grains. Journal of Food Engineering 82(2): 209216.

Fitzpatrick JJ, İqbal, T, Delaney C, Twomey T, Keogh MK (2004). Effect of powder properties and storage conditions on the flowability of milk powders with different fat contents. Journal of Food Engineering 64(4): 435-444.

Gezer İ, Haciseferoğulları H, Demir, F (2003). Some physical properties of Hacıhaliloğlu apricot pit and its kernel. Journal of Food Engineering 56(1): 4957.

Güngör F, Güvenç İ (1996). Türkiye'de tescilli fasulye çeşitlerine ait tohumların fiziksel özellikleri ve besin bileşimleri, Atatürk Üniversitesi Ziraat Fakültesi Dergisi 27(4): 524-529.

Kara M ve Öztürk İ (1997). Daneli Ürünlerin Orifislerden Akışı. Tarımsal Mekanizasyon 17. Ulusal Kongresi, 17-19 Eylül, 499-507, Tokat.

Kashaninejad M, Mortazavi A, Safekordi A, Tabil LG (2006). Some physical properties of Pistachio (Pistacia vera L.) nut and its kernel. Journal of Food Engineering 72(1): 30-38.

Mohsenin, NN (1986). Physical Properties of Plant and Animal Materials, second Edn. Gordon and Breach Science Publishers, New York.

Öztürk T, Kibar H, Esen B (2008a). Taneli Tarımsal Ürünler İçin Akış Profilleri ve Silolamada Karşılaşılan Sorunlar, GOÜ. Ziraat Fakültesi Dergisi 25(2): 61- 67

Öztürk T, Kibar H (2008b). Silindirik Fındık Depolama Yapılarında Depo Yükü Projeleme Parametreleri. OMÜ Ziraat Fakültesi Dergisi 23(2): 98- 103

Öztürk T, Kibar H (2008c). Silindirik Misır Depolama Yapılarında Tane Nem Kapsamına Bağlı Projeleme Yükleri. OMÜ Ziraat Fakültesi Dergisi 23(2): 110- 115

TÜİK (2021), Türkiye İstatistik Kurumu Verileri [Erişim tarihi:15.03.2021]. 